\author{
냉동변성방지제 조건에 따른 닭가슴살 수리미의 저장특성 \\ 진상근* • 김일석* • 최영준** • 박구부*** • 양한술*** • 김병균**** \\ 진주산업대학교 동물소재공학과*, 경상대학교 해양생물이용학부**, \\ 경상대학교 축산학전공***, 한성식품(주)****
}

\title{
Effect of Cryoprotectants on Quality Properties of Chicken Breast Surimi Manufactured by $\mathrm{pH}$ Adjustment
}

\author{
S. K. Jin*, I. S. Kim*, Y. J. Choi**, G. B. Park***, H. S. Yang*** and B. G. Kim**** \\ Department of Animal Resources Technology, Jinju National University*, Bioscience and Institute of \\ Marine Industry, Gyeongsang National University**, Department of Animal Science, Gyeongsang \\ National University***, Hansung Foods Co., Ltd.****
}

\begin{abstract}
This study was conducted to determine the effect of $\mathrm{pH}$ adjustment and the addition of cryoprotectants on the storage properties of chicken breast surimi. Surimi as a control was prepared with Alaska pollack by two times of washing treatment and addition of cryoprotectants (4\% sugar, $5 \%$ sorbitol and $0.3 \%$ polyphosphate). Three types of surimi were manufactured by different cryoprotectant conditions (T1: $5 \%$ sorbitol $+0.3 \%$ polyphosphate, T2: $4 \%$ sugar $+5 \%$ sorbitol $+0.3 \%$ polyphosphate, T3: $2 \%$ salt $+4 \%$ sugar + $5 \%$ sorbitol $+0.3 \%$ polyphosphate) and frozen after adjusting the surimi to $\mathrm{pH} 11.0$. The amino acid and saturated fatty acid composition were significantly higher in the control. EAA (essential amino acid), FAA (amino acid in relation to flavor), SAAA (amino acid in relation to saccarinity) and FRAA (fragrant amino acid) were significantly higher in the control. The TBARS (thiobarbituric acid reactive substances) and VBN (volatile basic nitrogen) were increased with storage times. TBARS and VBN values were significantly higher in the control and T3 than the other treatments. The VBN was significantly higher in control and T3 than other surimi samples. Chicken breast surimi adjusted to pH 11.0 had higher in microorganisms than the control, and T1 sample had the highest total plate count. Sensory evaluations were significantly higher in the control and T3 than the other samples. Especially, the overall acceptability of T3 was similar to the control.
\end{abstract}

(Key words : pH adjustment, Cryoprotectants, Chicken breast, Storage properties)

$$
\text { I. 서 론 }
$$

수리미는 어육을 이용하여 수세를 통해 혈 액, 지방, 효소 및 근장단백질을 분리 후 단백 질 안전성 향상을 위해 냉동 전 냉동변성방지 제를 혼합한 것 (Lee, 1984)으로 수리미 제조 시 수세 용액의 온도 및 $\mathrm{pH}$ 가 제품에 영향을 미
치며 (Lee와 Han, 1999), 수세 용매의 종류와 횟 수 또한 수리미의 품질에 영향을 미친다(Lee 등, 1999). 기존의 제조법인 수세법과 달리 최 근에 새롭게 개발된 산 $(\mathrm{pH}$ 2.5)과 알칼리 $(\mathrm{pH}$ 10.5) 용액에서 어육단백질을 용해시켜 회수시 킨 $\mathrm{pH}$ 조절법이 이용되어지고 있는데(Undeland 등, 2002), 이러한 조절법으로 제조된 수리미는

Corresponding author: H. S. Yang, Department of Animal Science, Gyeongsang National University, Jinju 660-701, Korea.

Tel : 82-55-757-2519, E-mail : hsyang1123@hanmail.net 
수세법과 비교하여 수용성단백질 손실을 줄일 수 있을 뿐만 아니라 높은 제품 수율을 가져온 다 (Lin과 Park, 1996).

근육식품을 보존하기 위한 가장 효과적인 과 정인 냉동의 낮은 저장 온도는 미생물 안전성 확보와 더불어 생화학적 반응을 가져오는 등 수리미 원료육의 기능적 변화를 최소화하기 위 해 필수적으로 사용된다. 그러나 냉동저장은 근육식품 품질에 확실히 불안정한 변화를 가져 오는 것으로 냉동을 통한 얼음 결정화는 근육 조직 및 특정 단백질의 부분적인 변성을 야기 한다 (Tomaniak 등, 1998). 또한 근원섬유단백질 을 변성시켜 기능적 특성을 약화시키므로 보수 성을 떨어뜨릴 뿐만 아니라 지질산화의 원인으 로 (Nilsson과 Ekstrand, 1995; Richards 등, 1998) 작용하는 바, 냉동저장 중 수리미 또는 수리미 의 원료가 되는 어육 및 축육의 품질은 저장 및 유통 중 조절이 중요시 된다 (Jittinandana 등, 2005).

이렇듯 냉동 중 단백질변성 및 지질산화로부 터 어육단백질을 장기간 저장하기 위하여 sucrose (4\%), sorbitol (4\%)과 polyphosphates (0.2\%) 등을 상업적으로 혼합 - 사용한 이후(Lee, 1984), 수 리미 제조 시 널리 사용되는 냉동변성방지제는 저분자량을 가진 당류와 sucrose, sorbitol과 같 은 polyol류 및 polyphosphate를 걸러낸 어육과 $1: 1$ 비율로 사용하거나 단독으로 $8 \%(\mathrm{w} / \mathrm{w})$ 이 내로 첨가하고 있다 (Ahn 등, 1999; Sych 등, 1990a). 또한 Ahn 등 (1999)은 수리미에 올리고 당을 첨가하여 냉동변성방지제로서의 이용가능 성을 보고하였다. 몇몇 냉동변성방지제들은 최 종 제품의 단맛을 증가시키는 단점을 지니나, 저렴한 비용뿐만 아니라 근원섬유단백질 변성 을 억제 및 백색 겔 제품의 갈변화 경향이 적 기 때문에 사용 횟수가 증가되고 있다 (MacDonald와 Lanier, 1991). 이러한 냉동변성방지제 에 대한 연구로는, 소의 심장육을 이용한 surimi-like materials 제조 시 냉동변성방지제의 첨가가 단백질 용해성 및 겔 형성에 효과가 있 으며 (Wang과 Xiong, 1998), 우육 (Park 등, 1993), 돈육 (Tomaniak 등, 1998), 계육(Uijttenboogaart 등, 1993), ling cod surimi (Shltanbawa와
Li-Chan, 1998) 및 lizardfish surimi (Ruttanapornvareesakul 등, 2006) 등에 대한 연구가 진행되었다. 그러나 현재 기존의 수세법과는 달리 $\mathrm{pH}$ 조절 법으로 제조된 닭가슴살 수리미의 냉동변성방 지제 첨가 효과에 관한보고는 이루어지지 않아 최근에 개발된 많은 장점을 지니고 있는 $\mathrm{pH}$ 조절법을 활용하여 닭가슴살을 이용한 수리미 제조 시 냉동변성방지제의 첨가 수준의 차이가 닭가슴살 수리미의 냉동 저장 중 수리미의 저 장 특성에 미치는 효과에 대해 알아보고자 실 시하였다.

\section{ㅍ. 재료 및 방법}

\section{1. 실험재료 및 수리미 제조 조건}

시험에 공시한 원료육은 수세법으로 제조되 어 냉동저장 중인 명태연육(수분 $80 \%$ )을 한성 식품(주에서 구매하여 대조구 원료로 활용하였 고, $\mathrm{S}$ 사에서 구입한 냉장 닭가슴살을 이용하여 근막과 지방을 제거하고 정형한 원료육 $5 \mathrm{~kg}$ 을 Chopper (MGB-32, Fugee Co., Korea)로 $3 \mathrm{~mm}$ 초핑한 후 Silent cutter (AS-30, Ramon Co., Spain)로 미세하게 4분간 커팅 후 6배 중량의 물을 가하여 Homogenizer (T25B, IKA Sdn. Bhd., Malaysia)로 8,000 rpm에서 30초간 균질하 였다. 균질액을 표준체 3.5 와 16 번으로 각각 여 과한 후 여과액에 $1 \mathrm{~N} \mathrm{NaOH}$ 를 이용하여 선행 연구 (Jung 등, 2004)에 따라 단백질 추출을 위 하여 알칼리 조건인 $\mathrm{pH}$ 11로 조절한 후 3 상 연속원심분리기 (J-1250, 한일과학, 한국)로 $10,000 \times \mathrm{g}$ 에서 25 분간 원심분리하여 최상층과 최하층은 버리고 중간층을 회수하였다. 회수된 시료는 $1 \mathrm{~N} \mathrm{HCl}$ 을 이용하여 육단백질의 등전 점인 $\mathrm{pH} 5.0$ 으로 조절한 후 단백질의 침전을 위해 30 분간 방치한 후 $10,000 \times \mathrm{g}$ 에서 25 분간 원심분리하였다. 하층의 회수된 수리미는 적외 선수분 측정기 (FD-240, Kett Co., Japan)로 수분 을 측정한 후 $80 \%$ 로 보정하였다. 수분이 보정 된 수리미 무게에 대해 Table 1과 같은 비율로 소금, 설탕 (백설탕, $\mathrm{CJ}, 100 \%$ ), 솔비톨 (Sigma, $100 \%)$ 및 인산염 [FOS/ENR, 태원, 폴리인산나 
Table 1. Experimental design by different cryoprotectants (unit; \%)

\begin{tabular}{ccccccc}
\hline Treatments & & Salt & Sugar & Sorbitol & Polyphosphate & Total \\
\hline \hline $\begin{array}{c}\text { Alaska pollack surimi } \\
\text { by two times washing }\end{array}$ & C & 0 & 4 & 5 & 0.3 & 9.3 \\
\hline & T1 & 0 & 0 & 5 & 0.3 & 5.3 \\
Chicken breast surimi & T2 & 0 & 4 & 5 & 0.3 & 9.3 \\
by pH 11 adjustment & T3 & 2 & 4 & 5 & 0.3 & 11.3 \\
\hline
\end{tabular}

트륨 40, 피로인산나트륨(무수) 30, 산성피로인 산나트륨 $30 \%$ ]을 냉동변성방지제로 첨가하여 총 4처리구로 하여 PVDC (polyvinylidenechloride) (diameter $3.0 \times 15 \mathrm{~cm}$ )에 충전하고 $-40^{\circ} \mathrm{C} / 36$ 시간 동결 후 $-10^{\circ} \mathrm{C}$ 에서 30 일간 냉동저장하면서 90 ${ }^{\circ} \mathrm{C} / 40$ 분 탕침 가열한 후 이화학적 및 관능 특 성을 분석하였다.

\section{2. 조사항목 및 방법}

\section{(1) 아미노산 조성}

아미노산 조성은 $\mathrm{AOAC}(2000)$ 방법에 따라 시료 약 $0.02 \mathrm{~g}$ 에 $6 \mathrm{~N} \mathrm{HCl} 15 \mathrm{~mL}$ 를 가하여, $110^{\circ} \mathrm{C}$ dry oven에서 24시간 이상 동안 산가수 분해한 후 $55^{\circ} \mathrm{C}$ Water bath에서 감압농축하여 $\mathrm{pH} 2.20$ sodium citrate buffer로 $25 \mathrm{~mL}$ Volumetric flask에 정용하여 아미노산자동분석기 (Biochrom 20, Pharm Tek, England)를 이용하여 Table 2와 같은 조건으로 분석하였다.

(2) 지방산 조성

지방산 조성은 시료를 Folch 등(1957)의 방법 을 이용하여 조지방을 추출한 후 추출된 조지 방 시료를 이용하여 Gas chromatography (Agilent,
6890N GC system, USA)로 분석하였다. 이 때 기기조건은 Table 3과 같다.

(3) 지방산패도

TBARS (thiobarbituric acid reactive substances) 는 Buege와 Aust (1978)의 방법에 따라 시료 5 g에 butylated hydroxyanisole (BHA) $50 \mu \mathrm{L}$ 와 증 류수 $15 \mathrm{~mL}$ 를 첨가하여 균질화 시킨 후 균질액 $1 \mathrm{~mL}$ 를 시험관에 넣고 여기에 $2 \mathrm{~mL}$ thiobarbituric acid(TBA)/trichloroacetic acid(TCA) 혼합 용액을 넣어 완전히 혼합한 다음, $90^{\circ} \mathrm{C}$ 의 항온 수조에서 15 분간 열처리한 후 냉각시켜 3,000 $\mathrm{rpm}$ 에서 10 분간 원심분리시켰다. 원심분리한 시료의 상층을 회수하여 $531 \mathrm{~nm}$ 에서 측정한 흡 광도에 5.88을 곱하여 mg MA(malonaldehyde)/ $\mathrm{kg}$ 으로 나타내었다.

\section{(4) 휘발성염기태질소화합물}

VBN(volatile basic nitrogen)은 高坂 (1975)의 방법에 따라 세절육 $3 \mathrm{~g}$ 에 증류수 $27 \mathrm{~mL}$ 를 가 하여 $14,000 \mathrm{rpm}$ 에서 30초간 균질한 후 균질액 을 여과지 (Whatman No. 1)로 여과하여 conway unit 접착부에 glycerine을 바르고 외실에 여과 액 $1 \mathrm{~mL}$ 를 넣고 내실에는 $0.01 \mathrm{~N} \mathrm{H}_{3} \mathrm{BO}_{3} 1 \mathrm{~mL}$

Table 2. Conditions of amino acid analyzer

\begin{tabular}{ll}
\hline \multicolumn{1}{c}{ Items } & \multicolumn{1}{c}{ Conditions } \\
\hline \hline Instrument & Biochrom 20, Pharm Tek, England \\
& Cation Separation Column LCA K06, 4.6 mm $\times 150 \mathrm{~mm}$ \\
Column & Catalog NO. 5112001 \\
& $570 \mathrm{~nm}$ and $440 \mathrm{~nm}$ \\
Absorbance & $0.25 \mathrm{~mL} / \mathrm{min}$ \\
Reagent flow rate & $0.45 \mathrm{~mL} / \mathrm{min}$ \\
Buffer flow rate & $130^{\circ} \mathrm{C}$ \\
Reactor temperature & $15 \mathrm{~m}$ \\
Reactor size & \\
\hline
\end{tabular}


Table 3. GC conditions for analysis of fatty acid

\begin{tabular}{ll}
\hline \multicolumn{1}{c}{ Items } & \multicolumn{1}{c}{ Conditions } \\
\hline \hline Instrument & Hewlett Packard 6890 gas chromatography \\
Column & $5 \%$ phenyl methyl siloxane $30 \mathrm{~m} \times 320 \mu \mathrm{m}$ \\
Temperature program & $5{ }^{\circ} \mathrm{C} / \mathrm{min}$ \\
Detector & Flame ionization detector (FID) \\
Initial temperature \& time & $50^{\circ} \mathrm{C} \& 1 \mathrm{~min}$ \\
Final temperature \& time & $200^{\circ} \mathrm{C} \mathrm{\&} 40 \mathrm{~min}$ \\
Injector \& detector temperature & $270^{\circ} \mathrm{C}$ \\
Carrier gas & $\mathrm{He}$ \\
Split ratio & $90: 1$ \\
\hline
\end{tabular}

와 지시약 $(0.066 \%$ methyl red $+0.066 \%$ bromocresol green)을 3 방울 $(30 \mu \ell)$ 가하여 뚜껑을 닫은 후 $50 \% \mathrm{~K}_{2} \mathrm{CO}_{3} 1 \mathrm{~mL}$ 를 외실에 신속히 주입 후 즉 시 밀폐시킨 다음 용기를 수평으로 교반하여 여과액과 $50 \% \mathrm{~K}_{2} \mathrm{CO}_{3}$ 을 잘 혼합시킨 후 $37^{\circ} \mathrm{C}$ 에 서 120 분간 배양하였다. 배양 후 $0.02 \mathrm{~N} \mathrm{H}_{2} \mathrm{SO}_{4}$ 로 내실의 붕산용액을 측정하여 $\mathrm{mg} \%$ 로 나타내 었다.

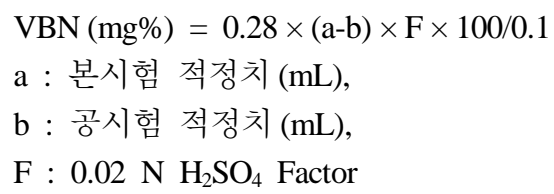

(5) 미생물 검사

총균수 (total plate counts)는 시료 $10 \mathrm{~g}$ 을 1\% peptone 수 $90 \mathrm{~mL}$ 에 넣고 Bagmixer (Interscience, German)로 균질시킨 다음 $1 \mathrm{~mL}$ 를 채취하여 준 비된 $9 \mathrm{~mL}$ peptone수에 넣어 희석한 후, 희석 액을 미리 조제한 배지 (plate count agar, Difco, $\mathrm{USA}$ )에 평판배양하여 $32^{\circ} \mathrm{C}$ 에서 2 일 배양하였 고, Salmonella는 희석액을 Shigella agar(Difco, $\mathrm{USA})$ 에 평판배양하여 $37^{\circ} \mathrm{C}$ 에서 1 일 배양하였 으며, 유산균 (Lactobacilli spp.)은 희석액을 Lactobacilli MRS agar(Difco, USA)에 평판배양하여 $30^{\circ} \mathrm{C}$ 에서 2 일 배양한 후 나타나는 colony의 수 를 각각 계수하였다.

\section{(6) 관능평가}

관능검사는 충진된 수리미를 $90^{\circ} \mathrm{C}$ 에서 40 분 탕침 가열한 후 잘 훈련된 10 명의 요원에 의해
9점 척도법으로 실시하였으며, 육색 (1-3 : 창백 함, 4-6 : 보통, 7-9 : 어두움), 향(1-3 : 약함, 4-6 : 보통, 7-9 : 강함), 연도(1-3 : 질김, 4-6 : 보통, 7-9 : 연함) 및 기호성 (1-3 : 좋지않음, 4-6 : 보통, 7-9 : 좋음)으로 표시하게 하여 관 능검사를 실시하였다.

\section{3. 통계분석}

이상의 실험에서 얻어진 결과는 SAS (1999) 의 GLM (General linear model) 방법으로 분석하 였으며, 처리 평균 간의 비교를 위해 Duncan의 Multiple range test가 이용하였다.

\section{III. 결과 및 고찰}

\section{1. 아미노산 및 지방산 조성}

$\mathrm{pH}$ 조절법과 냉동변성방지제 첨가에 따른 수리미의 저장 중 아미노산 및 지방산 조성 변 화는 Table 4, 5와 같다. 아미노산 조성 결과, 모든 아미노산 조성에서 대조구가 닭가슴살을 활용한 수리미보다 유의적으로 높게 나타났다 $(\mathrm{P}<0.05)$. 또한 대조구에는 저장기간이 증가할 수록 아미노산 조성별 차이를 보이지 않으나, 처리구들은 저장 30 일째 아미노산 함량이 증가 하는 것으로 나타났다. 특히 $\mathrm{EAA}$ (필수아미노 산), $\mathrm{FAA}$ (향기에 관련된 아미노산), $\mathrm{SAAA}$ (당 에 관련된 아미노산) 및 FRAA(방향성 아미노 산) 모두 Alaska pollack을 활용한 수리미인 대 조구에서 높게 나타났다 $(\mathrm{P}<0.05)$. 따라서 닭가 
Table 4. Effect of cryoprotectants on amino acid compositions (\%) of chicken breast surimi manufactured by $\mathrm{pH}$ adjustment during freozen storage at $-10^{\circ} \mathrm{C}$

\begin{tabular}{|c|c|c|c|c|c|}
\hline \multirow{2}{*}{ Amino acids } & \multirow{2}{*}{$\begin{array}{c}\text { Storage } \\
\text { days }\end{array}$} & \multicolumn{4}{|c|}{ Treatments $^{1)}$} \\
\hline & & $\mathrm{C}$ & $\mathrm{T} 1$ & $\mathrm{~T} 2$ & T3 \\
\hline \multirow{3}{*}{ Aspartic } & 0 & $2.28 \pm 0.05^{\mathrm{a}}$ & $1.69 \pm 0.02^{\mathrm{Bd}}$ & $1.82 \pm 0.03^{\mathrm{Ab}}$ & $1.76 \pm 0.02^{\mathrm{BC}}$ \\
\hline & 15 & $2.28 \pm 0.05^{\mathrm{a}}$ & $1.47 \pm 0.03^{\mathrm{Cb}}$ & $1.34 \pm 0.04^{\mathrm{Bc}}$ & $1.44 \pm 0.01^{\mathrm{Cb}}$ \\
\hline & 30 & $2.28 \pm 0.05^{\mathrm{a}}$ & $1.76 \pm 0.04^{\mathrm{Ac}}$ & $1.87 \pm 0.04^{\mathrm{Ab}}$ & $1.83 \pm 0.04^{\mathrm{Abc}}$ \\
\hline \multirow{3}{*}{ Threonine*, 3) } & 0 & $0.96 \pm 0.02^{\mathrm{a}}$ & $0.81 \pm 0.01^{\mathrm{BC}}$ & $0.88 \pm 0.02^{\mathrm{Bb}}$ & $0.83 \pm 0.02^{\mathrm{Bc}}$ \\
\hline & 15 & $0.96 \pm 0.02^{\mathrm{a}}$ & $0.66 \pm 0.01^{\mathrm{Cb}}$ & $0.59 \pm 0.02^{\mathrm{Cc}}$ & $0.63 \pm 0.02^{\mathrm{Cb}}$ \\
\hline & 30 & $0.96 \pm 0.02^{\mathrm{a}}$ & $0.87 \pm 0.03^{\mathrm{Ab}}$ & $0.94 \pm 0.02^{\mathrm{Aa}}$ & $0.90 \pm 0.05^{\text {Aab }}$ \\
\hline \multirow{3}{*}{ Serine $^{3)}$} & 0 & $0.95 \pm 0.02^{\mathrm{a}}$ & $0.67 \pm 0.01^{\mathrm{Bc}}$ & $0.71 \pm 0.02^{\mathrm{Bb}}$ & $0.66 \pm 0.02^{\mathrm{Bc}}$ \\
\hline & 15 & $0.95 \pm 0.02^{\mathrm{a}}$ & $0.59 \pm 0.01^{\mathrm{Cb}}$ & $0.54 \pm 0.01^{\text {Cc }}$ & $0.58 \pm 0.01^{\mathrm{Cb}}$ \\
\hline & 30 & $0.95 \pm 0.02^{\mathrm{a}}$ & $0.72 \pm 0.02^{\mathrm{Ac}}$ & $0.77 \pm 0.03^{\mathrm{Ab}}$ & $0.72 \pm 0.03^{\mathrm{Ac}}$ \\
\hline \multirow{3}{*}{ Glutamic $^{2)}$} & 0 & $4.09 \pm 0.11^{\mathrm{a}}$ & $2.88 \pm 0.02^{\mathrm{BC}}$ & $3.09 \pm 0.07^{\mathrm{Ab}}$ & $2.99 \pm 0.03^{\mathrm{Bbc}}$ \\
\hline & 15 & $4.09 \pm 0.11^{\mathrm{a}}$ & $2.57 \pm 0.01^{\mathrm{Cb}}$ & $2.40 \pm 0.04^{\mathrm{BC}}$ & $2.54 \pm 0.03^{\mathrm{Cb}}$ \\
\hline & 30 & $4.09 \pm 0.11^{\mathrm{a}}$ & $2.94 \pm 0.02^{\mathrm{Ac}}$ & $3.15 \pm 0.07^{\mathrm{Ab}}$ & $3.07 \pm 0.03^{\mathrm{Ab}}$ \\
\hline \multirow{3}{*}{ Proline } & 0 & $0.61 \pm 0.03^{\mathrm{ab}}$ & $0.59 \pm 0.01^{\mathrm{Bb}}$ & $0.64 \pm 0.01^{\mathrm{Ba}}$ & $0.59 \pm 0.04^{\mathrm{Ab}}$ \\
\hline & 15 & $0.61 \pm 0.03^{\mathrm{a}}$ & $0.42 \pm 0.02^{\mathrm{Cc}}$ & $0.45 \pm 0.01^{\mathrm{Cbc}}$ & $0.48 \pm 0.01^{\mathrm{Bb}}$ \\
\hline & 30 & $0.61 \pm 0.03^{\mathrm{a}}$ & $0.65 \pm 0.04^{\text {Aab }}$ & $0.71 \pm 0.04^{\mathrm{Aa}}$ & $0.64 \pm 0.03^{\mathrm{Ab}}$ \\
\hline \multirow{3}{*}{ Glycine $^{3)}$} & 0 & $0.78 \pm 0.01^{\mathrm{a}}$ & $0.59 \pm 0.02^{\mathrm{BC}}$ & $0.64 \pm 0.02^{\mathrm{Bb}}$ & $0.61 \pm 0.01^{\mathrm{Bc}}$ \\
\hline & 15 & $0.78 \pm 0.01^{\mathrm{a}}$ & $0.55 \pm 0.01^{\mathrm{Cb}}$ & $0.51 \pm 0.01^{\mathrm{Cc}}$ & $0.54 \pm 0.01^{\mathrm{Cb}}$ \\
\hline & 30 & $0.78 \pm 0.01^{\mathrm{a}}$ & $0.65 \pm 0.01^{\mathrm{Ac}}$ & $0.71 \pm 0.04^{\mathrm{Ab}}$ & $0.67 \pm 0.03^{\mathrm{Abc}}$ \\
\hline \multirow{3}{*}{ Alanine $^{3)}$} & 0 & $1.33 \pm 0.03$ & $1.02 \pm 0.01^{\mathrm{B}}$ & $0.77 \pm 0.57$ & $0.96 \pm 0.14$ \\
\hline & 15 & $1.33 \pm 0.03^{\mathrm{a}}$ & $0.94 \pm 0.02^{\mathrm{Cb}}$ & $0.87 \pm 0.00^{c}$ & $0.92 \pm 0.01^{\mathrm{b}}$ \\
\hline & 30 & $1.33 \pm 0.03^{\mathrm{a}}$ & $1.10 \pm 0.07^{\mathrm{Ab}}$ & $1.15 \pm 0.05^{\mathrm{b}}$ & $1.05 \pm 0.15^{\mathrm{b}}$ \\
\hline \multirow{3}{*}{ Valine ${ }^{*}$} & 0 & $1.13 \pm 0.01^{\mathrm{a}}$ & $0.91 \pm 0.01^{\mathrm{Bc}}$ & $0.97 \pm 0.01^{\mathrm{Bb}}$ & $0.96 \pm 0.01^{\mathrm{Bb}}$ \\
\hline & 15 & $1.13 \pm 0.01^{\mathrm{a}}$ & $0.78 \pm 0.01^{\mathrm{Cb}}$ & $0.73 \pm 0.01^{\text {Cc }}$ & $0.78 \pm 0.01^{\mathrm{Cb}}$ \\
\hline & 30 & $1.13 \pm 0.01^{\mathrm{a}}$ & $0.98 \pm 0.02^{\mathrm{Ab}}$ & $1.04 \pm 0.06^{\mathrm{Ab}}$ & $1.03 \pm 0.04^{\mathrm{Ab}}$ \\
\hline \multirow{3}{*}{ Isoleucine $^{*}$} & 0 & $1.10 \pm 0.03^{\mathrm{a}}$ & $0.92 \pm 0.01^{\mathrm{BC}}$ & $0.99 \pm 0.02^{\mathrm{Bb}}$ & $0.95 \pm 0.02^{\mathrm{BC}}$ \\
\hline & 15 & $1.10 \pm 0.03^{\mathrm{a}}$ & $0.81 \pm 0.01^{\mathrm{Cb}}$ & $0.76 \pm 0.02^{\mathrm{Cc}}$ & $0.81 \pm 0.00^{\mathrm{Cb}}$ \\
\hline & 30 & $1.10 \pm 0.03$ & $1.01 \pm 0.08^{\mathrm{A}}$ & $1.06 \pm 0.05^{\mathrm{A}}$ & $1.03 \pm 0.04^{\mathrm{A}}$ \\
\hline \multirow{3}{*}{ Leucine $^{*}$} & 0 & $1.88 \pm 0.06^{\mathrm{a}}$ & $1.47 \pm 0.01^{\mathrm{Ac}}$ & $1.60 \pm 0.03^{\mathrm{Bb}}$ & $1.53 \pm 0.02^{\mathrm{BC}}$ \\
\hline & 15 & $1.88 \pm 0.06^{\mathrm{a}}$ & $1.30 \pm 0.03^{\mathrm{Bb}}$ & $1.21 \pm 0.02^{\mathrm{Cc}}$ & $1.31 \pm 0.00^{\mathrm{Cb}}$ \\
\hline & 30 & $1.88 \pm 0.06^{\mathrm{a}}$ & $1.54 \pm 0.06^{\mathrm{Ac}}$ & $1.66 \pm 0.02^{\mathrm{Ab}}$ & $1.58 \pm 0.02^{\mathrm{Ac}}$ \\
\hline \multirow{3}{*}{ Tyrosine $^{4)}$} & 0 & $0.85 \pm 0.02^{\mathrm{a}}$ & $0.51 \pm 0.01^{\mathrm{Bd}}$ & $0.62 \pm 0.01^{\mathrm{Bb}}$ & $0.57 \pm 0.02^{\mathrm{BC}}$ \\
\hline & 15 & $0.85 \pm 0.02^{\mathrm{a}}$ & $0.55 \pm 0.01^{\mathrm{ABb}}$ & $0.52 \pm 0.01^{\mathrm{Cc}}$ & $0.53 \pm 0.01^{\mathrm{Cbc}}$ \\
\hline & 30 & $0.85 \pm 0.02^{\mathrm{a}}$ & $0.59 \pm 0.05^{\mathrm{Ac}}$ & $0.68 \pm 0.04^{\mathrm{Ab}}$ & $0.64 \pm 0.01^{\mathrm{Abc}}$ \\
\hline \multirow{3}{*}{ Phenylalanine ${ }^{*}$ 4) } & 0 & $0.82 \pm 0.06^{\mathrm{a}}$ & $0.60 \pm 0.01^{\mathrm{Bb}}$ & $0.66 \pm 0.01^{\mathrm{Bb}}$ & $0.61 \pm 0.03^{\mathrm{b}}$ \\
\hline & 15 & $0.82 \pm 0.06^{\mathrm{a}}$ & $0.66 \pm 0.02^{\mathrm{Ab}}$ & $0.61 \pm 0.03^{\mathrm{Cb}}$ & $0.64 \pm 0.01^{\mathrm{b}}$ \\
\hline & 30 & $0.82 \pm 0.06^{\mathrm{a}}$ & $0.67 \pm 0.03^{\mathrm{Ab}}$ & $0.74 \pm 0.04^{\text {Aab }}$ & $0.68 \pm 0.07^{\mathrm{b}}$ \\
\hline \multirow{3}{*}{ Histidine* } & 0 & $0.55 \pm 0.02^{\mathrm{a}}$ & $0.44 \pm 0.02^{\mathrm{Bb}}$ & $0.45 \pm 0.02^{\mathrm{Bb}}$ & $0.44 \pm 0.01^{\mathrm{Bb}}$ \\
\hline & 15 & $0.55 \pm 0.02^{\mathrm{a}}$ & $0.48 \pm 0.01^{\mathrm{ABc}}$ & $0.46 \pm 0.01^{\mathrm{Bd}}$ & $0.50 \pm 0.00^{\mathrm{Ab}}$ \\
\hline & 30 & $0.55 \pm 0.02$ & $0.53 \pm 0.06^{\mathrm{A}}$ & $0.53 \pm 0.04^{\mathrm{A}}$ & $0.50 \pm 0.03^{\mathrm{A}}$ \\
\hline
\end{tabular}


Table 5. Effect of cryoprotectants on fatty acid compositions (\%) of chicken breast surimi manufactured by $\mathrm{pH}$ adjustment during frozen storage at $-10^{\circ} \mathrm{C}$

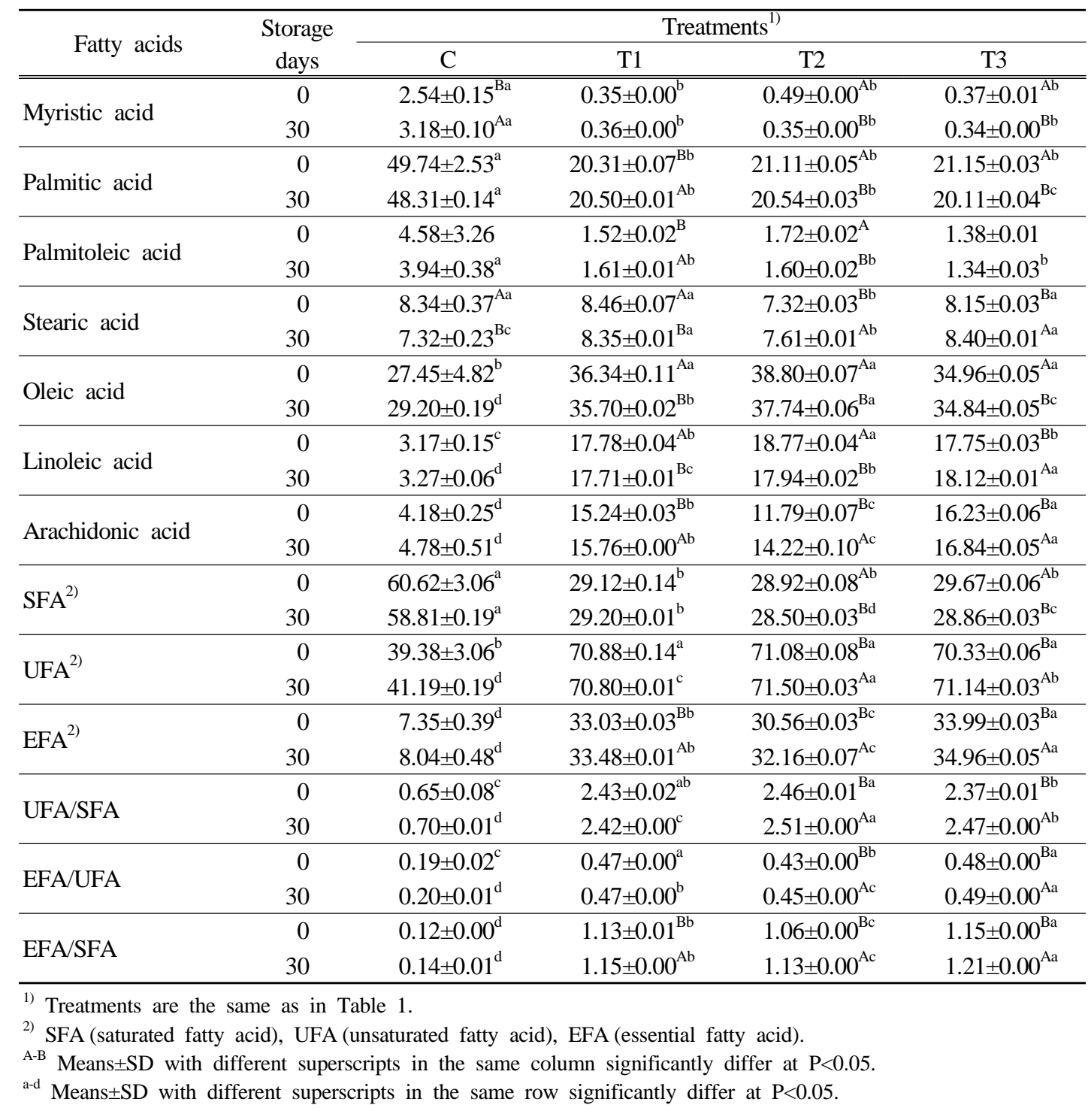

슴살을 활용한 수리미에 비해 Alaska pollack을 수리미 제조를 위한 원료육으로 활용할 경우 필수아미노산 및 방향성 아미노산 함량이 증가 된다는 MacDonald와 Lanier (1991)의 보고와 일 치하였다. 또한 처리구간엔 저장 30 일째를 기 준으로 비교해보면, T2에서 높은 FAA, FRAA 및 SAAA 함량을 보여 냉동변성방지제의 첨가 수준별 차이가 아미노산 조성에 영향을 미치지 않는 것을 알 수 있다.
일반적으로 바다생선이 민물생선에 비해 높 은 불포화지방산 함량을 가지나 (Sikorski 등, 1990) 닭고기의 지방산 조성과의 비교시 생선 에서는 palmitoleic acid의 함량이 높으며 특히 불포화지방산 중 $n-3$ 지방산의 함량이 높게 나 타나며, 닭고기에서는 linoleic acid가 높게 나타 났다(Horng 등, 2002). 따라서 본 실험의 지방 산 조성 결과, 대조구에서 처리구에 비해 myristic acid, palmitic acid 및 palmitoleic acid 
Table 6. Effect of cryoprotectants on TBARS, VBN and aW of chicken breast surimi manufactured by $\mathrm{pH}$ adjustment during frozen storage at $-10^{\circ} \mathrm{C}$

\begin{tabular}{cccccc}
\hline \multirow{2}{*}{ Items } & Storage & \multicolumn{4}{c}{ Treatments $^{1)}$} \\
\cline { 3 - 6 } & days & $\mathrm{C}$ & $\mathrm{T} 1$ & $\mathrm{~T} 2$ & $\mathrm{~T} 3$ \\
\hline \hline \multirow{2}{*}{ TBARS } & 0 & $1.23 \pm 0.34^{\mathrm{Bb}}$ & $1.23 \pm 0.06^{\mathrm{Bb}}$ & $1.87 \pm 0.10^{\mathrm{Ba}}$ & $1.32 \pm 0.04^{\mathrm{Bb}}$ \\
$(\mathrm{mg} / \mathrm{kg})$ & 15 & $1.07 \pm 0.13^{\mathrm{Ba}}$ & $0.46 \pm 0.06^{\mathrm{Cb}}$ & $0.51 \pm 0.00^{\mathrm{Cb}}$ & $0.21 \pm 0.11^{\mathrm{Cc}}$ \\
& 30 & $2.01 \pm 0.29^{\mathrm{Aa}}$ & $1.40 \pm 0.06^{\mathrm{Ab}}$ & $2.09 \pm 0.04^{\mathrm{Aa}}$ & $1.58 \pm 0.07^{\mathrm{Ab}}$ \\
\hline \multirow{2}{*}{$\mathrm{VBN}$} & 0 & $22.49 \pm 2.45^{\mathrm{Aa}}$ & $2.10 \pm 0.14^{\mathrm{Bb}}$ & $2.55 \pm 0.95^{\mathrm{b}}$ & $3.22 \pm 0.92^{\mathrm{Bb}}$ \\
$(\mathrm{mg} \%)$ & 15 & $22.00 \pm 1.69^{\mathrm{Aa}}$ & $2.26 \pm 0.45^{\mathrm{Bb}}$ & $2.08 \pm 0.29^{\mathrm{b}}$ & $3.06 \pm 1.17^{\mathrm{Bb}}$ \\
& 30 & $16.29 \pm 2.03^{\mathrm{Ba}}$ & $3.13 \pm 0.16^{\mathrm{Ac}}$ & $3.43 \pm 1.15^{\mathrm{C}}$ & $8.87 \pm 3.50^{\mathrm{Ab}}$ \\
\hline & 0 & $0.95 \pm 0.00^{\mathrm{ABb}}$ & $0.97 \pm 0.00^{\mathrm{a}}$ & $0.97 \pm 0.00^{\mathrm{a}}$ & $0.95 \pm 0.00^{\mathrm{b}}$ \\
$\mathrm{a}$ & 15 & $0.94 \pm 0.01^{\mathrm{B}}$ & $0.96 \pm 0.02$ & $0.97 \pm 0.01$ & $0.96 \pm 0.01$ \\
& 30 & $0.96 \pm 0.00^{\mathrm{A}}$ & $0.97 \pm 0.01$ & $0.97 \pm 0.01$ & $0.96 \pm 0.00$ \\
\hline
\end{tabular}

1) Treatments are the same as in Table 1.

${ }^{\text {A-C }}$ Means \pm SD with different superscripts in the same column significantly differ at $\mathrm{P}<0.05$.

${ }^{\mathrm{a}-\mathrm{c}}$ Means $\pm \mathrm{SD}$ with different superscripts in the same row significantly differ at $\mathrm{P}<0.05$.

함량이 높게 나타난 반면, oleic acid, linoleic acid 및 arachidonic acid 함량은 낮게 나타났다 $(\mathrm{P}<0.05)$. 이러한 결과들은 대조구에서 높은 포 화지방산 함량과 낮은 불포화지방산 함량을 반 영한다. 그러나 대조구는 저장기간에 따른 함 량의 변화가 없는 반면, 포화지방산 함량은 $\mathrm{T} 2$ 및 $\mathrm{T} 3$ 에서 저장기간이 증가할수록 감소하며, 불포화지방산 함량은 증가하였다 $(\mathrm{P}<0.05)$. 또한 필수지방산 함량의 경우, $\mathrm{T} 3$ 에서 가장 높은 값 을 보이며, 처리구들은 저장기간이 증가할수록 증가됨을 알 수 있다.

\section{2. 지방산패도, 휘발성염기태질소화합물 및 수분활성도}

$\mathrm{pH}$ 조절법과 냉동변성방지제 첨가에 따른 수리미의 저장 중 지방산패도 (TBARS), 휘발성 염기태질소화합물 $(\mathrm{VBN})$ 및 수분활성도 $\left(\mathrm{a}_{\mathrm{w}}\right)$ 변 화는 Table 6과 같다. 지방산패도는 육과 육제 품의 지질산화를 나타내며 주로 TBARS 값으 로 분석된다 (Jo와 Ahn, 2000). 지방산패도는 저 장 30 일째 대조구와 $\mathrm{T} 2$ 에서 높게 나타나며, $\mathrm{T} 1$ 및 $\mathrm{T} 3$ 에서 낮게 나타났다 $(\mathrm{P}<0.05)$. 또한 모든 처리구에서 15 일째까지는 감소하다가 30 일째에 는 증가되는 것으로 나타났다. 이는 Alaska pollack 및 닭가슴살을 활용한 냉동 수리미의
지질산화가 저장 15 일째 이후에 발생되는 것으 로 판단된다. 특히 같은 함량의 sorbitol 및 polyphosphate 함량에 4\% sugar만을 첨가한 대조구 및 $\mathrm{T} 2$ 에서 높은 $\mathrm{TBA}$ 값을 나타내었다. 일반적 으로 sucrose와 sorbitol은 어육단백질을 안정화 시켜 겔 형성 능력 (Park 등, 1996) 및 염용성단 백질 함량 (Sych 등, 1990) 증가에 효과가 있는 것으로 알려져 있으나, 이와 달리 앞의 지방산 조성 결과와 같이 저장 30 일차 $\mathrm{T} 2$ 에서의 높은 불포화지방산 함량으로 인해 TBA값이 높게 나 타난 것으로 판단되며, 대조구 또한 어육 자체 의 상대적으로 높은 불포화지방산 함량의 결과 라 판단된다.

휘발성염기태질소화합물 $(\mathrm{VBN})$ 의 경우, $\mathrm{T} 1$ 및 $\mathrm{T} 3$ 는 저장기간이 증가할수록 높은 $\mathrm{VBN}$ 값 을 보였으나, $\mathrm{T} 2$ 는 저장기간별 차이를 나타내 지 않았으며, 대조구는 오히려 감소하여 저장 30 일째에 가장 낮은 값을 나타내었다. 특히 닭 가슴살을 활용한 처리구들에 비해 Alaska pollack을 활용한 대조구에서 월등히 높은 $\mathrm{VBN}$ 값을 보여준다 $(\mathrm{P}<0.05)$. Riebroy 등 $(2007)$ 은 저 장기간이 증가할수록 bigeye snapper 원료육 및 수리미의 $\mathrm{VBN}$ 값이 증가하며, 저장 15 일째 뿔 돔 (bigeye snapper) 수리미의 $\mathrm{VBN}$ 값이 18 $\mathrm{mg} / \%$ 로 Alaska pollack을 활용한 대조구와 유사 한 값을 나타내었다. 또한 저장 30일째에 닭가 
슴살을 활용한 수리미 중 $\mathrm{T} 1$ 및 $\mathrm{T} 2$ 에 비해 $\mathrm{T} 3$ 에서 높은 $\mathrm{VBN}$ 함량을 보여준다. 동일한 첨가 량의 sorbitol 및 polyphosphate에 아무것도 첨가 하지 않은 $\mathrm{T} 2$ 에 비해 $4 \%$ sugar를 첨가한 $\mathrm{T} 3$ 가 높은 $\mathrm{VBN}$ 함량을 보이며, $4 \%$ sugar에 $2 \%$ salt
를 첨가한 $\mathrm{T} 3$ 에서 높게 나타났다 $(\mathrm{P}<0.05)$. 따라 서 냉동변성방지제 중 sugar 및 salt는 $\mathrm{VBN}$ 함 량에 영향을 미치는 것으로 판단된다.

수분활성도 결과, 다른 처리구에 비해 대조 구는 저장기간별 수분활성도 값에 차이를 보이

Table 7. Effect of cryoprotectants on microorganisms of chicken breast surimi manufactured by $\mathrm{pH}$ adjustment during frozen storage at $-10^{\circ} \mathrm{C}$

\begin{tabular}{cccccc}
\hline \multirow{2}{*}{ Items } & Storage & \multicolumn{4}{c}{ Treatments $^{1)}$} \\
\cline { 3 - 6 } & days & $\mathrm{C}$ & $\mathrm{T} 1$ & $\mathrm{~T} 2$ & $\mathrm{~T} 3$ \\
\hline \hline \multirow{2}{*}{$\mathrm{TPC}$} & 0 & $3.46 \pm 0.02^{\mathrm{Ad}}$ & $4.67 \pm 0.19^{\mathrm{Ca}}$ & $4.74 \pm 0.03^{\mathrm{Ba}}$ & $4.83 \pm 0.07^{\mathrm{Aa}}$ \\
$\left(\log _{10}\right.$ CFU/g) & 15 & $3.37 \pm 0.13^{\mathrm{Ad}}$ & $5.43 \pm 0.02^{\mathrm{Aa}}$ & $5.12 \pm 0.06^{\mathrm{Ab}}$ & $4.42 \pm 0.05^{\mathrm{Bc}}$ \\
& 30 & $2.07 \pm 0.10^{\mathrm{Bc}}$ & $5.06 \pm 0.15^{\mathrm{Ba}}$ & $3.85 \pm 0.09^{\mathrm{Cb}}$ & $3.68 \pm 0.09^{\mathrm{Cb}}$ \\
\hline \multirow{2}{*}{ Salmonella } & 0 & $2.89 \pm 0.01^{\mathrm{Ac}}$ & $4.67 \pm 0.03^{\mathrm{Ba}}$ & $4.36 \pm 0.04^{\mathrm{Bb}}$ & $4.25 \pm 0.30^{\mathrm{ABb}}$ \\
$\left(\log _{10}\right.$ CFU/g) & 15 & $1.65 \pm 0.49^{\mathrm{Bc}}$ & $5.35 \pm 0.18^{\mathrm{Aa}}$ & $4.97 \pm 0.02^{\mathrm{Aab}}$ & $4.78 \pm 0.08^{\mathrm{Ab}}$ \\
& 30 & $\mathrm{ND}^{2)}$ & $4.08 \pm 0.22^{\mathrm{Cab}}$ & $4.36 \pm 0.06^{\mathrm{Ba}}$ & $3.75 \pm 0.45^{\mathrm{Bb}}$ \\
\hline \multirow{2}{*}{ Lactobacillus $_{\left(\log _{10} \text { CFU/g) }\right.}$} & 0 & $1.94 \pm 0.06^{\mathrm{b}}$ & $2.04 \pm 0.13^{\mathrm{b}}$ & $2.20 \pm 0.17^{\mathrm{b}}$ & $2.62 \pm 0.33^{\mathrm{a}}$ \\
& 15 & $\mathrm{ND}$ & $\mathrm{ND}$ & $\mathrm{ND}$ & $\mathrm{ND}$ \\
\hline
\end{tabular}

1) Treatments are the same as in Table 1.

2) ND: No detected.

A-C Means \pm SD with different superscripts in the same column significantly differ at $\mathrm{P}<0.05$.

${ }^{\mathrm{a}-\mathrm{d}}$ Means $\pm \mathrm{SD}$ with different superscripts in the same row significantly differ at $\mathrm{P}<0.05$.

Table 8. Effect of cryoprotectants on sensory scores ${ }^{1)}$ of chicken breast surimi manufactured by $\mathrm{pH}$ adjustment during frozen storage at $-10^{\circ} \mathrm{C}$

\begin{tabular}{cccccc}
\hline \multirow{2}{*}{ Items } & $\begin{array}{c}\text { Storage } \\
\text { days }\end{array}$ & \multicolumn{4}{c}{ Treatments $^{2)}$} \\
\cline { 2 - 5 } & 0 & $5.16 \pm 0.75^{\mathrm{Ba}}$ & $3.17 \pm 0.41^{\mathrm{C}}$ & $2.83 \pm 0.75^{\mathrm{C}}$ & $4.17 \pm 0.41^{\mathrm{Bb}}$ \\
\hline \multirow{3}{*}{ Color } & 15 & $6.33 \pm 0.52^{\mathrm{Aa}}$ & $3.00 \pm 0.89^{\mathrm{C}}$ & $3.50 \pm 0.45^{\mathrm{C}}$ & $5.33 \pm 1.03^{\mathrm{Ab}}$ \\
& 30 & $5.17 \pm 0.75^{\mathrm{Ba}}$ & $3.00 \pm 0.63^{\mathrm{b}}$ & $3.50 \pm 0.55^{\mathrm{b}}$ & $5.33 \pm 0.82^{\mathrm{Aa}}$ \\
\hline \multirow{2}{*}{ Flavor } & 0 & $5.01 \pm 0.63^{\mathrm{a}}$ & $2.83 \pm 0.75^{\mathrm{bc}}$ & $2.17 \pm 0.41^{\mathrm{Cc}}$ & $3.00 \pm 0.63^{\mathrm{Cb}}$ \\
& 15 & $5.00 \pm 0.54^{\mathrm{a}}$ & $2.83 \pm 0.41^{\mathrm{b}}$ & $3.00 \pm 0.63^{\mathrm{Bb}}$ & $4.50 \pm 0.45^{\mathrm{Ba}}$ \\
& 30 & $5.50 \pm 0.55^{\mathrm{a}}$ & $2.66 \pm 0.52^{\mathrm{C}}$ & $3.67 \pm 0.52^{\mathrm{Ab}}$ & $5.83 \pm 0.41^{\mathrm{Aa}}$ \\
\hline \multirow{2}{*}{ Tenderness } & 0 & $4.83 \pm 0.41^{\mathrm{b}}$ & $6.83 \pm 0.41^{\mathrm{Aa}}$ & $6.83 \pm 0.41^{\mathrm{Aa}}$ & $6.66 \pm 0.52^{\mathrm{a}}$ \\
& 15 & $5.17 \pm 0.75^{\mathrm{ab}}$ & $3.50 \pm 1.22^{\mathrm{Bc}}$ & $4.67 \pm 1.21^{\mathrm{Bbc}}$ & $6.33 \pm 1.03^{\mathrm{a}}$ \\
\hline \multirow{2}{*}{ Overall } & 30 & $5.17 \pm 0.75^{\mathrm{ab}}$ & $4.33 \pm 1.03^{\mathrm{Bb}}$ & $5.17 \pm 0.98^{\mathrm{Bab}}$ & $5.83 \pm 0.75^{\mathrm{a}}$ \\
acceptability & 0 & $5.00 \pm 0.40^{\mathrm{a}}$ & $4.17 \pm 0.15^{\mathrm{Ab}}$ & $3.87 \pm 0.41^{\mathrm{b}}$ & $4.63 \pm 0.27^{\mathrm{Ba}}$ \\
& 15 & $5.26 \pm 0.34^{\mathrm{a}}$ & $3.03 \pm 0.44^{\mathrm{Bc}}$ & $3.70 \pm 0.41^{\mathrm{b}}$ & $5.89 \pm 0.65^{\mathrm{Aa}}$ \\
& 30 & $5.10 \pm 0.41^{\mathrm{b}}$ & $3.03 \pm 0.53^{\mathrm{Bd}}$ & $3.97 \pm 0.43^{\mathrm{C}}$ & $5.87 \pm 0.70^{\mathrm{Aa}}$ \\
\hline
\end{tabular}

${ }^{1)}$ Color (1-3 : pale, 4-6 : normal, 7-9 : dark), flavor (1-3: weak, 4-6 : moderate, 7-9 : strong), tenderness (1-3

: tough, 4-6 : moderate, 7-9 : soft), Acceptability (1-3 : dislike, 4-6 : moderate, 7-9 : like).

2) Treatments are the same as in Table 1.

A-C Means $\pm S D$ with different superscripts in the same column significantly differ at $\mathrm{P}<0.05$.

${ }^{\mathrm{a}-\mathrm{d}}$ Means $\pm \mathrm{SD}$ with different superscripts in the same row significantly differ at $\mathrm{P}<0.05$. 
며, $\mathrm{T} 1$ 및 $\mathrm{T} 2$ 에서 대조구와 $\mathrm{T} 3$ 에 비해 저장 0 일째에 높은 값을 나타내었다 $(\mathrm{P}<0.05)$. 수분활 성도는 미생물이 이용할 수 있는 수분 지표를 나타내는 용어로, 일반적으로 미생물은 높은 수분활성도를 필요로 한다. 그러나 염과 같은 용질을 첨가하여 미생물이 수분을 이용하지 못 하게 함으로써 감소시킬 수 있다 (Thorarinsdottir 등, 2001). 그러나 모든 처리구에서 저장 15일 이후 수분활성도 값에 차이를 보이지 않아 냉 동변성방지제의 첨가 수준의 차이가 수리미의 수분활성도 값엔 영향을 미치지 않는 것으로 판단된다.

\section{3. 미생물 수}

$\mathrm{pH}$ 조절법과 냉동변성방지제 첨가에 따른 수리미의 저장 중 총세균수, 살모넬라 및 락토 바실러스균수의 변화를 Table 7에서 나타내었 다. 처리구들 간의 비교 시 $\mathrm{T} 1$ 구에서 모든 저 장기간에서 유의적으로 높은 총균수가 나타나 며 $(\mathrm{P}<0.05)$, 모든 처리구에서 저장 15 일째까지 는 증가하다가 30 일째에는 감소하는 경향을 보 여준다. 살모넬라균은 대조구는 저장기간이 증 가할수록 감소하나, 처리구들은 저장 15 일째까 지는 증가하다가 30 일째에는 감소하는 것으로 나타나 총균수와 유사한 경향을 보였다. 또한 Alaska pollack을 활용한 대조구에서 낮은 살모 넬라균수를 보이며, $\mathrm{T} 1$ 및 $\mathrm{T} 2$ 구에서 높은 균수 를 보여준다 $(\mathrm{P}<0.05)$. 보편적으로 적용되는 $\mathrm{HACCP}$ 기준지표를 근거하면 도축후 소나 돼 지도체에서 살모넬라균수는 불검출되는 것으로 알려져 있다. 그러나 대조구를 비롯한 닭고기 를 활용한 처리구들에서 높은 값의 살모넬라균 수를 보인 것은 Nissen 등 (2001)의 보고한 steam vacuum의 방법으로 오염을 제거시킨 닭 가슴살의 초기 살모넬라수는 $3.5 \mathrm{CFU} / \mathrm{cm}^{2}$ 으로 무 처리한 대조구와 차이를 보이지 못하며, 1 $0{ }^{\circ} \mathrm{C}$ 에서 4 일 저장시 $7 \mathrm{CFU} / \mathrm{cm}^{2}$ 수준으로 증가 하였다는 보고와 같이 소나 돼지도체에 비해 닭도체에서의 살모넬라 발생율이 높은 것으로 판단된다.

락토바실러균은 저장 15일 및 30일째 모든
처리구에서 검출되지 않았으나, 저장 0 일째 때 $\mathrm{T} 3$ 구에서 높은 값을 나타내었다. 어육 및 축육 에서 검출되는 대표적인 젖산균으로서는 Lactobacillus sp. 및 Pediococcus sp.로 분류되며 (Tanasupawat 등, 1993), Riebroy 등 (2006)은 어 육을 이용한 수리미를 15 일 동안 저장 시 $10^{8}$ $\mathrm{CFU} / \mathrm{g}$ 정도의 젖산균수가 검출되는 것으로 보 고하였다. 이러한 미생물수는 사후 원료육의 수분활성도 및 $\mathrm{pH}$ 변화에 따라 좌우되며, 높은 수분활성도 및 $\mathrm{pH}$ 조건일 때 미생물 성장이 유리하다(Calicioglu 등, 2003). 따라서 본 연구 에서는 원료육과 냉동변성방지제의 차이에 따 른 $\mathrm{pH}$ 값은 미제시 하였으나, 대조구에 비해 처리구가 높은 총균수 및 살모넬라균수를 나타 낸 것은 원료육 차이는 물론 수리미의 $\mathrm{pH}$ 차 이에 의한 것으로 판단된다.

\section{4. 관능평가}

$\mathrm{pH}$ 조절법과 냉동변성방지제 첨가에 따른 수리미의 저장 중 관능특성 평가를 Table 8에 서 나타내었다. 색을 포함한 모든 관능평가 항 목에서 대조구와 $\mathrm{T} 3$ 에서 $\mathrm{T} 1$ 과 $\mathrm{T} 2$ 에 비해 높은 선호도를 보였다 $(\mathrm{p}<0.05)$. 또한 처리구별 비교 시 소금과 설탕을 첨가하지 않은 $\mathrm{T} 1$ 에 비해 첨 가량이 증가할수록 높게 나타났다 $(\mathrm{P}<0.05)$.

\section{IV. 요 약}

$\mathrm{pH}$ 조절법을 활용하여 닭가슴살을 이용한 수리미 제조 시 냉동변성방지제의 첨가 수준의 차이가 닭가슴살 수리미의 냉동 저장 중 수리 미의 저장 특성에 미치는 효과에 대해 알아보 고자, 대조구 (Alaska pollack에 수세법을 활용하 여 냉동변성방지제인 4\% sugar, $5 \%$ sorbitol 및 $0.3 \%$ polyphosphate를 첨가)와, 닭가슴살을 이용 하여 $\mathrm{pH}$ 조절법으로 제조된 처리구 (T1: 5\% sorbitol and 0.3\% polyphosphate, T2: 4\% sugar, $5 \%$ sorbitol and $0.3 \%$ polyphosphate, and $\mathrm{T} 3$ : 2\% salt, 4\% sugar, 5\% sorbitol and $0.3 \%$ polyphosphate) 들로 나눠 실험에 공시하였다.

아미노산 조성에서 대조구가 처리구들보다 
유의적으로 높게 나타났다. 또한 대조구는 저 장기간이 증가할수록 아미노산 조성별 차이를 보이지 않았으나, 처리구들은 저장 30 일째 아 미노산 함량이 증가하는 것으로 나타났다. 지 방산 조성의 경우, 대조구가 처리구에 비해 myristic acid, palmitic acid 및 palmitoleic acid 등이 높게 나타났으며, oleic acid, linoleic acid 및 arachidonic acid 함량은 낮게 나타났다 $(\mathrm{P}<0.05)$. 그러나 대조구는 저장기간에 따른 함 량의 변화가 없는 반면, 포화지방산 함량은 $\mathrm{T} 2$ 및 $\mathrm{T} 3$ 에서 저장기간이 증가할수록 감소하였으 며, 불포화지방산 함량은 증가하였다.

지방산패도는 모든 처리구에서 15일째까지는 감소하다가 저장 30 일째에는 증가하였다. 처리 간에는 저장 30 일째에 대조구와 $\mathrm{T} 2$ 에서 높게 나타났으며, T1 및 $\mathrm{T} 3$ 에서 낮은 지방산패도를 나타내었다 $(\mathrm{P}<0.05)$. 특히 대조구 및 $\mathrm{T} 2$ 에서 높 은 지방산패도를 나타내었다. 휘발성염기태질 소화합물 $(\mathrm{VBN})$ 의 경우, $\mathrm{T} 1$ 및 $\mathrm{T} 3$ 는 저장기간 이 증가할수록 높은 값을 보였으나, $\mathrm{T} 2$ 는 저장 기간별 차이를 나타내지 않았으며, 대조구는 오히려 감소하여 저장 30 일째에는 가장 낮은 값을 나타내었다. 특히 닭가슴살을 활용한 처 리구들에 비해 대조구가 월등히 높은 $\mathrm{VBN}$ 값을 나타내었다. 수분활성도의 경우 다른 처리구에 비해 대조구는 저장기간별 수분활성도에 차이 를 보였으며, 처리 간에는 $\mathrm{T} 1$ 및 $\mathrm{T} 2$ 가 대조구 와 $\mathrm{T} 3$ 에 비해 저장 0 일째에 높은 값을 나타내 었다.

총세균수는 모든 처리구에서 저장 15 일째까 지는 증가하다가 저장 30 일째에는 감소하였으 며, 처리 간에는 $\mathrm{T} 1$ 이 모든 저장기간에서 유의 적으로 높은 총균수를 나타내었다. 살모넬라균 의 경우 대조구는 저장기간이 증가할수록 감소 하였으나, 처리구들은 저장 15 일째까지는 증가 하다가 30 일째에는 감소하는 것으로 나타나 총 균수와 유사한 경향을 보였다. 처리 간에는 대 조구에 비해 $\mathrm{T} 1$ 및 $\mathrm{T} 2$ 가 높은 균수를 나타내 었다. 락토바실러스균은 저장 0 일째에 $\mathrm{T} 3$ 에서 높은 값을 나타내었으나, 저장 15일 및 30일째 모든 처리구에서 검출되지 않았다. 또한 관능 평가 결과, 색을 포함한 모든 관능평가 항목에
서 대조구와 $\mathrm{T} 3$ 에서 $\mathrm{T} 1$ 과 $\mathrm{T} 2$ 에 비해 높은 선 호도를 보였다. 또한 처리구별 비교 시 소금과 설탕을 첨가하지 않은 $\mathrm{T} 1$ 에 비해 첨가량이 증 가할수록 높게 나타났다.

이상의 결과를 종합해보면, 처리구들에 비해 대조구가 아미노산 및 포화지방산 함량은 높게 나타났으며, 낮은 미생물 수를 나타내었다. 그 러나 지방산패도 및 $\mathrm{VBN}$ 값은 높게 나타나 대 조구의 저장성에 나쁜 영향을 미칠 것으로 판 단된다. 또한 $2 \%$ 소금 및 $4 \%$ 설탕을 첨가한 $\mathrm{T} 3$ 에서 $\mathrm{T} 1$ 과 $\mathrm{T} 2$ 에 비해 높은 선호도를 보여 냉동변성방지제의 첨가가 수리미의 관능특성을 개선시킬 수 있을 것으로 판단된다.

$$
\mathrm{V} \text {. 사 사 }
$$

이 논문은 농림기술개발사업(105128-3) 지원 에 의하여 연구된 것으로 이에 감사드립니다.

\section{VI. 인 용 문 헌}

1. Ahn, J. H., Lee, H. G., Kim, J. W., Kim, J. C., Yoon, H. S. and Park, K. H. 1999. Highly concentrated branched oligosaccharides as cryoprotectant for surimi. J. Food Sci. 64:418-422.

2. AOAC 2000. Official method of analysis $\left(15^{\text {th }} \mathrm{ed}\right)$. Arlington, VA: Association of Official Analytical Chemists. Washington, DC.

3. Buege, J. A. and Aust, J. D. 1978. Microsomal lipid peroxidation. Methods Enzymol. 52:302-309.

4. Calicioglu, M., Sofos, J. N. and Kendall, P. A. 2003. Fate of acid-adapted and non-adapted Esherichia coli O157: H7 inoculated post-drying on beef jerky treated with marinades before drying. Food Microbiol. 20:169-177.

5. Folch, J., Lees M. and Sloane-Stanley, G. H. 1957. A simple method for the isolation and purification of total lipids from animal tissues. J. Biol. Chem. 226:497-507.

6. Jittinandana, S., Kenney, P. B. and Slider, S. D. 2005. Cryoprotectants affect physical properties of restructured trout during frozen storage. J. Food Sci. 70:35-42. 
7. Jo, C. and Ahn, D. U. 2000. Volatiles and oxidatives changes in irradiated pork sausage with different fatty acid composition and tocopherol content. J. Food Sci. 65:270-275.

8. Jung, C. H., Kim, J. S., Jin, S. K., Kim, I. S., Jung, K. J. and Choi, Y. J. 2004. Gelation properties and industrial application of functional protein from fish muscle-2. Properties of functional protein gel from fish, chicken breast and pork leg and optimum formulation. J. Kor. Soc. Food Sci. Nutr. 33:1676-1684.

9. Lee, C. M. 1984. Surimi process technology. Food Tech. 38:69-80.

10. Lee, S. K. and Han, J. H. 1999. Effects of washing temperature and $\mathrm{pH}$ on the quality of surimi from mechanically deboned chicken meat. Kor. J. Food Sci. 19:268-277.

11. Lee, S. K., Han, J. H., Kang, C. G., Lee, M. and Kim, B. C. 1999. Washing solution and cycle affected quality properties of surimi from mechanically deboned chicken meat. Korean J. Anim. Sci. 41:687-696.

12. Lin, J. H., Lin, Y. H. and Kuo, C. C. 2002. Effect of dietary fish oil on fatty acid composition, lipid oxidation and sensory property of chicken frankfurters during storage. Meat Sci. 60:161-167.

13. Lin, T. M. and Park, J. W. 1996. Extraction of proteins from Pacific whitening mince at various washing conditions. J. Food Sci. 61:432-438.

14. MacDonald, G. A. and Lanier, T. C. 1991. Carbohydrates as cryoprotectant for meat and surimi. Food Technol. 45:150-159.

15. Nissen, H., Maugesten, T. and Lea, P. 2001. Survival and growth of Escherichia coli O157:H7, Yersinia enterocolitica and Salmonella enteritidis on decontaminated and untreated meat. Meat Sci. 57:291-298.

16. Nilsson, K. and Ekstrand, B. 1995. Sensory and chemically measured effects of different freeze treatments on the quality of farmed rainbow trout. J. Food Qual. 18:177-191.

17. Park, J. W., Lanier, T. C. and Pilkington, D. H. 1993. Cryostabilization of functional properties of pre-rigor and post-rigor beef by dextrose polymer and/or phosphates. J. Food Sci. 58:467-472.

18. Park, J. W., Brewer, M. S., McKeith, F. K., Becheter, P. J. and Novakofski, J. 1996. Salt, cryoprotectants and preheating temperature effects on surimi-like meterial from beef or pork. J. Food Sci. 61:790-795.

19. Richards, M. P., Kelleher, S. D. and Hultin, H. O. 1998. Effect of washing with or without antioxidants on quality retention of mackerel fillets during refrigerated and frozen storage. J. Agric. Food Chem. 46:4363-4371.

20. Riebroy, S., Benjakul, S., Visessanguan, W. and Tanaka, M. 2007. Effect of iced storage of bigeye snapper (Priacanthus tayenus) on the chemical composition, properties and acceptability of Som-fug, a fermented Thai fish mince. Food Chem. 102:270-280.

21. Ruttanapornvareesakul, Y., Somjit, K., Otsuka, A., Hara, K., Osatomi, K., Osako, K., Kongpun, O. and Nozaki, Y. 2006. Cryoprotective effects of shrimp head protein hydrolysate on gel forming ability and protein denaturation of lizardish surimi during frozen storage. Fisheres Sci. 72:421-428.

22. SAS. 1999. SAS/STAT Software for PC. Release 6.11, SAS Institute Inc. Cary, NC, USA.

23. Shltanbawa, Y. and Li-Chan, E. C. 1998. Cryoprotective effects of sugar and polyol blends in ling cod surimi during frozen storage. Food Res. Inter. 31:87-98.

24. Sikorski, Z. E., Kolakowska, A. and Pan, B. S. 1990. The nutritive composition of the major groups of marine food organisms. Seafood: Resiurces nutritional composition and preservation, Z, E. Sikorski (Ed), Boca Ration, FL, U.S.A., p. 29-54.

25. Sych, J., Lacroix, C., Adambounou, L. T. and Castaigne, F. 1990. Cryoprotective effect of lactitol, palatinit, and polydextrose on cod surimi proteins during frozen storage. J. Food Sci. 55:356-360.

26. Tanasupawat, S., Okada, S., Suzuki, K., Kazaki, M. and Komagata, K. 1993. Lactic acid bacteria, particularly heterofermentative Lactobacilli, found 
in fermented foods in Thailand. Bul. Jap. Fed. Cul. Col. 9:65-78.

27. Thorarinsdottir, K. A., Arason, S., Bogason, S. G. and Kristbergsson, K. 2001. Effects of phosphate on yield, quality, and water-holding capacity in the processing of salted cod (Gadusmorhua). J. Food Sci. 66:821-826.

28. Tomaniak, A., Tyszkiewicz, I. and Komosa, J. 1998. Cryoprotectants for frozen red meats. Meat Sci. 50:365-371.

29. Uijttenboogaart, T. G., Trziszka, T. L. and Shereurs, F. J. G. 1993. Cryoprotectant effects during short-time frozen storage of chicken myofibrillar protein isolates. J. Food Sci. 58:274-
277.

30. Undeland, I., Kelleher, S. D. and Hultin, H. O. 2002. Recovery of functional proteins from herring (Clupeaharengus) light muscle by an acid or alkaline solubilization process. J. Agric. Food Chem. 50:7371-7379.

31. Wang, B. and Xiong, Y. 1998. Functional stability of antioxidant-washed, cryoprotectant-treated beef heart surimi during frozen storage. J. Food Sci. 63:293-298.

32. 高坂和久. 1975. 肉製品の鮮度保持と測定. 食品 工業. 18:105-111.

(접수일자 : 2007. 11. 19. / 채택일자 : 2008. 2. 18.) 